\title{
PENDIDIKAN DI INDONESIA MEMPRIHATINKAN
}

\author{
Oleh: Sujarwo, M.Or \\ Dosen PJKR Fakultas Ilmu Keolahragaan, UNY
}

\section{Pendahuluan}

Pendidikan adalah hal pokok yang akan menopang kemajuan suatu bangsa. Kemajuan suatu bangsa dapat diukur dari kualitas dan sistem pendidikan yang ada. Tanpa pendidikan, suatu negara akan jauh tertinggal dari negara lain. Kualitas pendidikan di Indonesia pada dewasa ini sangat memprihatinkan. Ini dibuktikan di antaranya oleh data UNESCO (2000) tentang peringkat Indeks Pengembangan Manusia (Human Development Index), yaitu komposisi dari peringkat pencapaian pendidikan, kesehatan, dan penghasilan per kepala yang menunjukkan bahwa indeks pengembangan manusia Indonesia makin menurun. Di antara 174 negara di dunia, Indonesia menempati urutan ke-102 pada 1996, ke-99 pada 1997, ke105 pada 1998, dan ke-109 pada 1999. Selain itu, bukti nyata dari kemerosotan pendidikan di Indonesia adalah terjadinya tawuran, tingkat pelajar maupun mahasiswa. Aksi tawuran yang biasanya dipicu masalah sepele, dampaknya sangatlah besar. Masyarakat di seluruh dunia akan menyaksikan lewat media cetak maupun elektronik amburadulnya pendidikan di Indonesia.

Menurut survai Political and Economic Risk Consultant (PERC), kualitas pendidikan di Indonesia berada pada urutan ke-12 dari 12 negara di Asia. Posisi itu berada di bawah Vietnam. Data yang dilaporkan The World Economic Forum Swedia (2000), Indonesia memiliki daya saing yang rendah, hanya menduduki urutan ke-37 dari 57 negara yang disurvai di dunia. Kualitas pendidikan Indonesia yang rendah itu juga ditunjukkan data Balitbang (2003), bahwa dari 146.052 SD di Indonesia ternyata hanya 8 sekolah saja yang mendapatkan pengakuan dunia dalam kategori The Primary Years Program (PYP). Dari 20.918 SMP di Indonesia ternyata juga hanya 8 sekolah yang mendapatkan pengakuan dunia dalam kategori The Middle Years Program (MYP). Dan, dari 8.036 SMA ternyata hanya 7 sekolah saja yang mendapatkan pengakuan dunia dalam kategori The Diploma Program (DP).

Saat ini Indonesia sedang berusaha untuk memperbaiki sistem pendidikan yang ada dan akan menetapkan kurikulum 2013, dengan berbagai "tuntutan" bagi peserta didik. Beberapa waktu yang lalu, program pemerintah setiap tahun akan meningkatkan standar 
kelulusan ujian nasional (UN) hingga mencapai kesetaraan dengan negara maju (Puskomda Surabaya Raya: 10 Mei 2008).
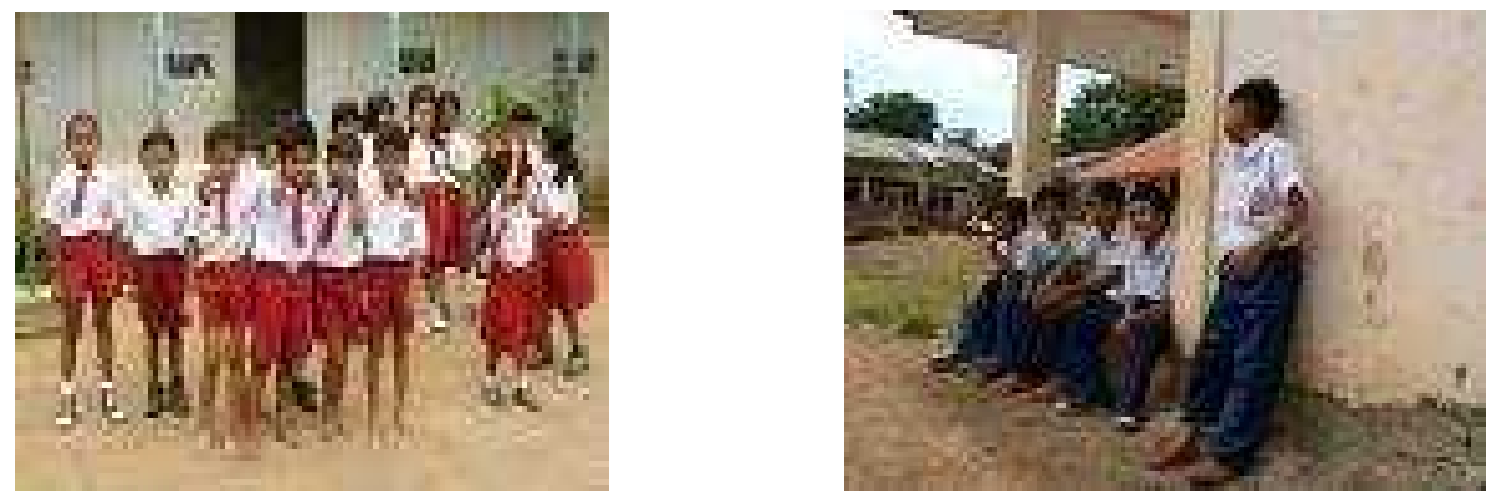

Sumber Gambar: diunduh dari internet

\section{Pembahasan}

Dalam artikel ini dilakukan pengelompokan pendidikan di Indonesia ke dalam dua bagian, yaitu: (1) arah dan tujuan pendidikan di Indonesia, dan (2) potret pendidikan di Indonesia antara harapan dan kenyataan.

\section{A. Arah dan Tujuan Pendidikan di Indonesia.}

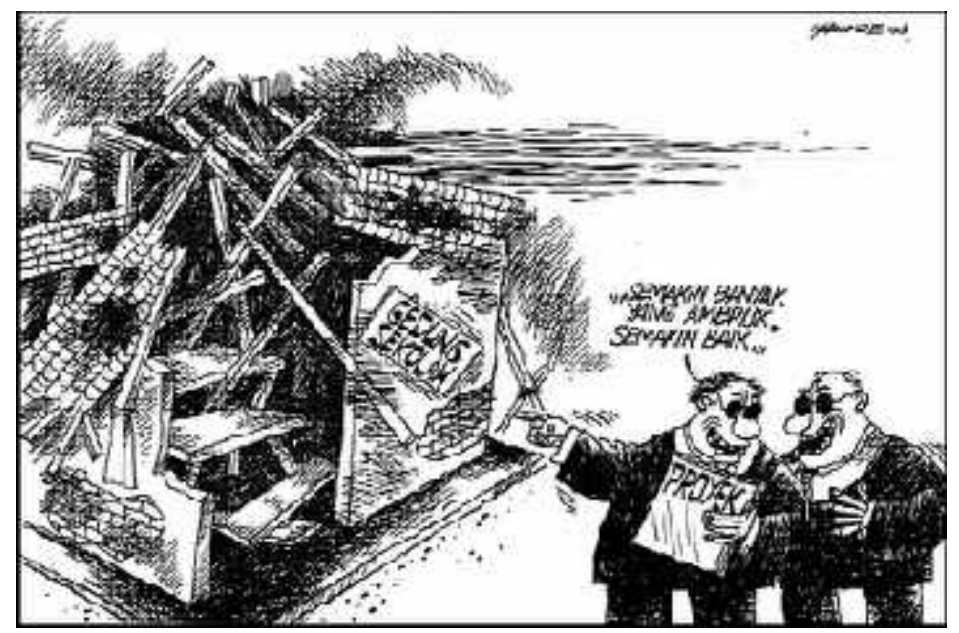

Fenomena dalam ilustrasi gambar di atas bagi oknum-oknum tertentu mungkin membersit dalam benaknya. Tidak sedikit sarana dan prasarana pendidikan di Indonesia yang masih membutuhkan perhatian pemerintah, misalnya: gedung sekolah, alat-alat laboratorium, buku-buku di perpustakaan, dan sarana prasarana pendukung lain. Pendidikan Indonesia sudah kehilangan arah. Pendidikan di Indonesia dalam bentuk sekolah telah tercabut dari akar kesejarahan sistem pendidikan nasional. Pendidikan di Indonesia sudah tidak lagi bertumpu pada nilai-nilai dasar pendidikan yang memerdekakan, pendidikan yang menyadarkan, 
pendidikan yang memanusiakan manusia muda, dan pengangkatan manusia muda ke taraf insani. Salah satu buktinya, pemerintah sekarang sedang menggalakkan pendidikan tingkat satuan pendidikan menengah atas berbasis kerja, yaitu sekolah menengah kejuruan (SMK). Pemerintah berencana akan mengubah pola pendidikan Indonesia dengan perbandingan 70\% untuk SMK dan 30\% untuk sekolah menengah atas (SMA). Lulusan SMA dalam pandangan pemerintah hanya menghasilkan lulusan yang tidak siap kerja kalau tidak mau disebut pengangguran. Meskipun sekolah sudah menerapkan beberapa tipe atau kelas dalam program di antaranya: kelas akselerasi, bilingual, RSBI atau SBI, atau sekolah yang hanya berstandar SSN. Namun, dampak yang didapatkan dengan program ataupun kelas-kelas dalam sekolah tersebut bukan jawaban yang pas untuk mengarahkan pendidikan terhadap tujuan pendidikan nasional bahwa dengan pendidikan diharapkan seseorang bisa menjadi manusia yang seutuhnya.

Pergantian kurikulum maupun pergantian menteri bisa dikatakan progresif, namun juga bukan suatu pemecahan masalah karena implementasi dan kualitas sumber daya manusia khususnya pendidik di Indonesia yang terlalu beragam. Pendidikan di negeri ini sejauh ini hanya mengadopsi tren yang sedang berkembang di negara lain, yang Indonesia selalu bercermin dari negara-negara yang sudah maju, misalnya Amerika, Australia, dan juga Inggris. Pendidikan karakter, local wisdom atau kearifan lokal, kewirausahaan yang diintegrasikan, merupakan salah satu program yang sia-sia, karena pendidikan yang memegang peranan penting, yaitu pendidikan di dalam keluarga dan masyarakat tidak bisa sejalan dan seimbang.
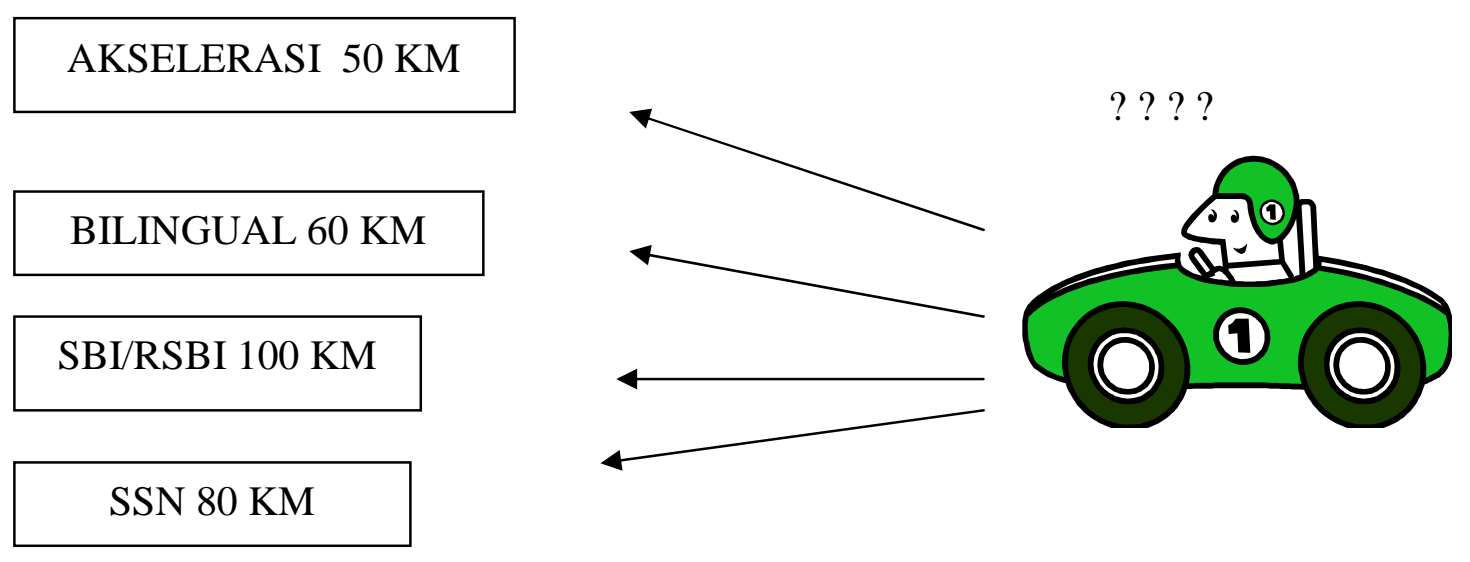

Gambar: ilustrasi penulis.

\section{B. Potret Pendidikan di Indonesia antara Harapan dan Kenyataan}




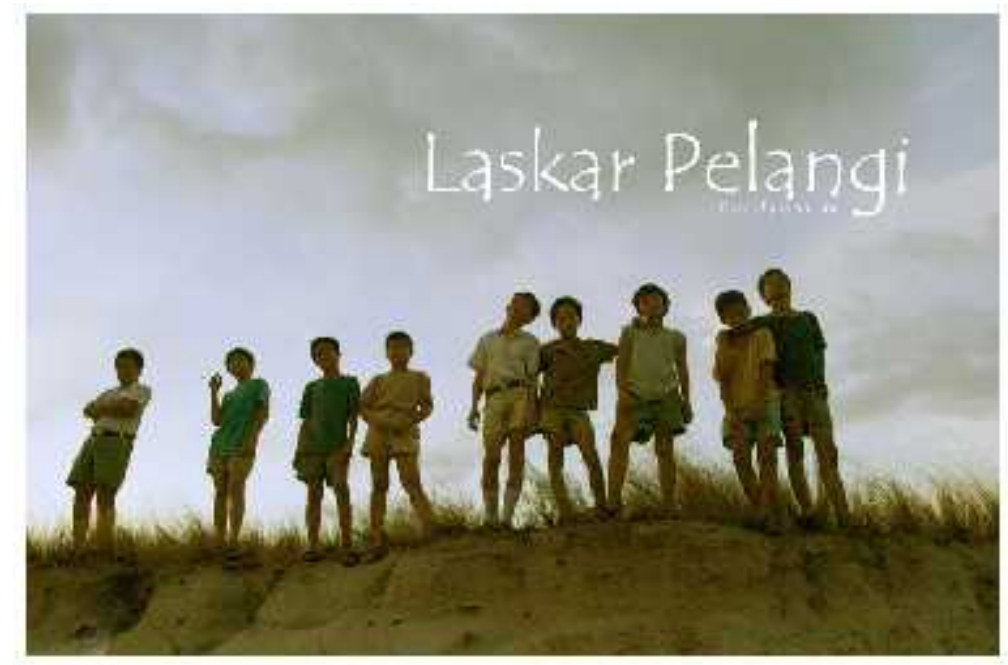

Gambar: "Laskar Pelangi" dan potret pendidikan Indonesia dulu sampai kini. (Jumat, 10 Oktober 2008, pk. 13:55:40, oleh: anonim)

Film "Laskar Pelangi" telah menyedot perhatian masyarakat di Indonesia termasuk Presiden Republik Indonesia, Dr. H. Susilo Bambang Yudhoyono. Film yang diambil dari novel karya novelis muda Andrea Herata ini menjadi film yang paling ditunggu dan tiketnya selalu terjual habis setiap harinya mulai sejak dirilis 25 September tempo hari.

Film ini menceritakan potret kehidupan anak-anak di pulau Belitung tahun 1970-an yang ingin menimba ilmu di tengah-tengah kesulitan ekonomi keluarga. Bagaimana seorang anak mengayuh sepeda sejauh puluhan kilometer melewati hutan dan rawa yang dihuni buaya ganas untuk mencari ilmu di sekolah. Selain menceritakan perjalanan anak-anak dalam menimba ilmu, film ini juga menceritakan pengabdian seorang guru (Ibu Muslimah) yang dengan tulus ikhlas mengajar walau hanya dibayar dengan beberapa liter beras.

Film Laskar Pelangi yang berlandaskan kisah nyata ini memberikan wawasan bagaimana potret pendidikan di Indonesia, bukan hanya di tahun 1970-an seperti dalam cerita Laskar Pelangi, namun apa yang terjadi di film tersebut masih terjadi sekarang ini seperti di Momogu, Asmat, Papua. Adolof seorang penjaga sekolah juga terpaksa mengajar, agar anakanak di sana tidak buta huruf. Dengan kemampuannya yang terbatas, ia hanya mengajarkan pelajaran Matematika dan bahasa Indonesia. Menurutnya, kegiatan belajar seadanya ini akan lebih baik daripada sekolahnya tertutup rumput seperti sekolah-sekolah yang lain.

Terdapat pesan yang sangat dalam dari film tersebut, yaitu kata-kata Pak Cik (Pak Harfan), Kepala Sekolah SD Muhammadiyah Belitong yang dipimpinnya, "Yang harus kalian ingat, anak-anakku, jangan cepat menyerah. Hiduplah untuk memberi sebanyakbanyaknya, bukan menerima sebanyak-banyaknya". Demikian kira-kira pesan Pak Cik. 
Siapakah yang akan menjadi Pak Cik-Pak Cik selanjutnya, siapakah yang akan memiliki semangat seperti Ibu Muslimah selanjutnya. Dan, siapakah yang akan menjadi siswa-siswa seperti Laskar Pelangi selanjutnya. Bukan di mana dan bagaimana belajar, tetapi bagaimana mimpi (cita-cita) itu menjadi pegangan untuk menggapai masa depan. Seperti syair lagu grup musik Nidji yang merupakan lagu tema Laskar Pelangi.

\section{Mimpi adalah kunci}

Untuk kita menaklukan dunia

Berlarilah tanpa lelah

Sampai engkau meraihnya...

(Laskar Pelangi-Nidji)

Berdasarkan fenomena yang diangkat dari novel maupun film di atas, kemudian ditelaah lebih jauh dengan melihat kenyataan di lapangan, ternyata potret pendidikan di Indonesia masih merupakan mimpi anak negeri yang entah tercapai atau tidak, karena bagi sebagian orang mungkin mimpi tersebut bisa diimbangi dengan kemampuan-kemampuan yang lain yang dimiliki anak atau keluarga anak tersebut, begitu juga sebaliknya. Sebagian siswa bisa dilihat perjuangannya dalam melawan medan untuk mencapai sekolah dalam rangka memperoleh pendidikan. Namun, perjuangan saja belum cukup untuk mampu meraih suatu mimpi dalam hidupnya. Masih masif jika dilihat siswa berprestasi yang berasal dari keluarga menengah ke bawah, peraih medali di olimpiade sains maupun olimpiade ilmiah lainnya, didominasi dari anak-anak dari golongan menengah ke atas.

\section{Penutup}

Pendidikan di Indonesia sampai saat ini belum jelas akan ke mana arahnya, belum bisa merata antara daerah satu dan daerah yang lain. Pemerintah sampai saat ini masih mengalami kebingungan apa yang akan mereka harapkan dan mereka pakai untuk menuju masyarakat pembelajar di negeri ini. Sehingga, banyak nilai pelajaran yang diambil dari luar atau diadopsi dari negera-negara yang sudah maju. Meskipun ada sisi positifnya, namun juga tidak boleh dikesampingkan sisi negatif dari pengadopsian kurikulum dari negara lain.

Pihak sekolah, pemerintah, dan masyarakat bahu-membahu dalam upaya mengembangkan bangsa melalui jalur pendidikan. Karena, tanpa adanya saling bekerjasama tidak mungkin semua akan tercapai dengan baik. Sebagai harapan kami nilai-nilai religi harus selalu sebagai landasan bagi semua pihak dalam melaksanakan roda pendidikan ini. Semoga bangsa ini segera sembuh dari keterpurukan dan pembodohan yang tersistematis. 


\section{DAFTAR PUSTAKA}

Anonim. 2008. Potret Dunia Pendidikan Indonesia. http://mybluegreen.net/taktaulah/potret-dunia-pendidikan-indonesia/. Diunduh pada 11 Januari 2008.

Irna. 2008. Potret Pendidikan di Indonesia. Diunduh pada 11 Januari 2008. http://irna1001.wordpress.com/2008/05/10/potret-pendidikan-di-indonesia/.

Nixon Erzed. 2008. Ke Mana Arah Pendidikan IT Indonesia? http://itsociety.blogspot.com/2008/04/kemana-arah-pendidikan-it-indonesia.html. Diunduh pada 9 Januari 2008.

Puskomda Surabaya Raya. 2008. Potret Pendidikan Indonesia. http://www.fsldkn.org/keummat-an/potret-pendidikan-indonesia.html. Diunduh pada 8 Januari 2008.

Sugeng Prayitno. 2007. Arah Pendidikan yang Salah Penyebab Meningkatnya Pengangguran di Indonesia. http://id.shvoong.com/social-sciences/1671760-arahpendidikan-yang-salah-penyebab/. Diunduh pada 13 Januari 2008.

UPY. 2008. "Laskar Pelangi" dan Potret Pendidikan Indonesia Dulu sampai Kini. http://www.upy.ac.id/site/?pilih=news\&mod=yes\&aksi=lihat\&id=37. Diunduh pada 13 Januari 2008. 